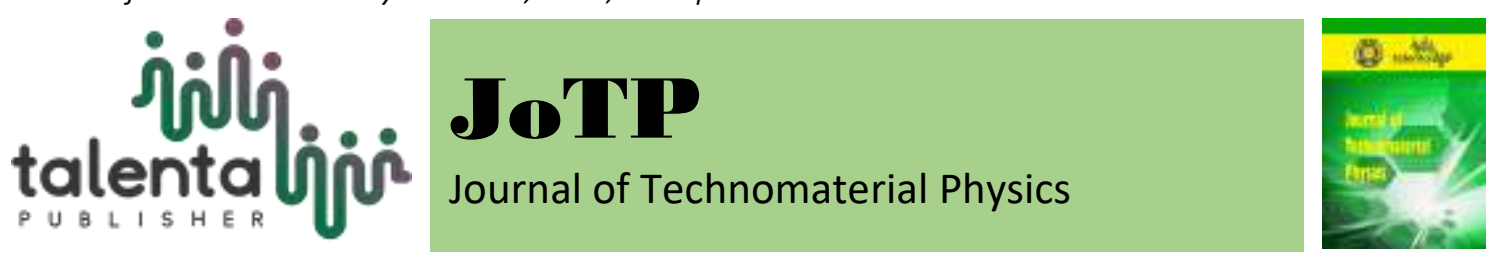

\title{
The Fabrication of Roof Tiles Utilizing Palm Oil Boiler Ash and Used Rubber Thread Fibers Waste
}

\author{
Achiruddin', Awan Maghfirah ${ }^{2}$, Anwar Dharma Sembiring ${ }^{3}$ and Hardi \\ Dido Sofyan ${ }^{4}$ \\ 1,2,3,4 Department of Physics, Faculty of Mathematics and Natural Science, Universitas Sumatera Utara \\ 20155, Indonesia
}

\begin{abstract}
Polymer composite roof tiles are produced from palm oil boiler ash and used rubber thread fibers waste. The material was strengthened by asphalt through a molding and pressurized conventional technique of sand, palm oil boiler ash waste, rubber thread fibers waste, asphalt and epoxy resin mixture. The composition of boiler ash and rubber thread fibers varied of $20 \%: 0 \%, 18 \%: 2 \%, 16 \%: 4 \%, 14 \%: 6 \%, 12 \%: 8 \%, 10 \%: 10 \%$. The results were tested for physical (density and water absorption), mechanical (compressive, impact and tensile strength) and thermal (Differential Thermal Analysis) properties. The characterization shows that the optimum mixture of sand, ash, thread, asphalt and resin compositions are 55\%:12\%:8\%:10\%: $15 \%$ respectively, with the highest density of $1.64 \mathrm{gram} / \mathrm{cm}^{3}$, waster absorption value of $1.72 \%, 77.68 \mathrm{~kJ} / \mathrm{m} 2$ impact value, $19.373 \mathrm{MPa}$ tensile strength and $360^{\circ} \mathrm{C}$ for differential thermal analysis temperature. Those results meet the SNI standard for existing roof tiles. This shows that the materials used in the research can be a cheap and environmentally friendly alternative to roof tile raw materials.
\end{abstract}

Keyword: polymer composite roof tiles, palm oil boiler ash, tire thread fibers.

Received 20 April 2019 | Revised [20 August 2019] | Accepted [31 August 2019]

\section{Introduction}

Tiles are objects serve as the roof of a building. They are the main part of a building as the cover or the roof. Tiles used to be made of molded clay which was heated to dry. The main function of roof tiles is to protect from sun heat and rain [1-3]. With the development of science, nowadays there are many additional materials used in the making of roof tiles such as waste material. Waste is substances obtained during the process of production, the residue or something useless. Usually it is disposed as it is not what the process aims to produce [4-7] .

The era development during globalization and the rapid improvement of technology have resulted in the emergence of consumable goods that leads to waste production often being used for some needs. Nowadays, North Sumatra is known as one of the provinces with many resources, palm oil is one of them. Crude Palm Oil (CPO) is estimated to reach 13.6 million

\footnotetext{
*Corresponding author at: Jl. Bioteknologi No.1 Kampus USU, Medan, Indonesia, 20155

E-mail address: achiruddin1954@yahoo.com
} 
tons in the nation annually. The side-product of its processes is solid fibrous waste from the bunches, seed fibers and palm kernel shell are known as palm oil boiler ash which reaches 20 million tons production per year. The process and utilization of palm oil waste to reach zero waste production is being encouraged [8-11]. The plantations and palm oil processing plants in Indonesia, especially North Sumatra, are growing rapidly because the area has a good potential in producing vegetable oil [12-15].

Palm kernel shell boiler ash is a type of biomass with silica $\left(\mathrm{SiO}_{2}\right)$ content that has the potential to be used [16-18]. The ash obtained from palm kernel shell and fruit fibers has $31.45 \%$ silica $\left(\mathrm{SiO}_{2}\right)$ and $15.2 \%$ of lime $(\mathrm{CaO})$ content [19-20]. The study about polymer tiles made of natural raw materials and waste have started to develop. This study explains the fabrication and characterization of polymer composites roof tiles using pressed method. The raw materials used in the making of polymer composites roof tiles were: sand, palm oil boiler ash, used rubber thread fibers, asphalt and epoxy resin.

\section{Materials and Methods}

The materials used in this research were oil palm boiler ash waste, sand, 60/70 penetrated asphalt, thread fibers from used rubber, and epoxy resin. The tools used were a spatula, a 100 mesh sieve, aluminum foil, beaker glass, mold, wax, brush, scissors, a digital balance, a mixer, a set of flexural test device, a set of impact test device, a hot press machine, and a set of Differential Thermal Analysis (DTA) test tools.

The materials used in the fabrication of polymer composites tiles were sand, oil palm boiler ash, rubber thread fibers, asphalt, and epoxy resin. The composition between boiler ash and thread fibers varied from $(20: 0,18: 2,16: 4,14: 6,12: 8,10: 10) \mathrm{g}$. Whereas the ratio for sand, asphalt and epoxy resin used were $55 \mathrm{~g}: 10 \mathrm{~g}: 15 \mathrm{~g}$.

$10 \mathrm{~g}$ of asphalt was put into a beaker glass and heated at $150^{\circ} \mathrm{C}$ until it melted. Then, $55 \mathrm{~g}$ fine sand sieved with 100 mesh was added, followed by $20 \mathrm{~g}$ of boiler ash and $0 \mathrm{~g}$ of thread fibers. All the materials were mixed well together. The mixture was cooled down for 5 minutes before $15 \mathrm{~g}$ of epoxy resin was added into it and they were mixed together. Afterwards, the mixture was poured into the mold. The sample obtained was tested for: density, water absorption, impact strength, flexural strength and Differential Thermal Analysis (DTA).

\section{Result and Discussion}

\subsection{Physical Properties Analysis}

The water absorption capacity test refers to ASTM C-20-00-2005 about testing procedures. It aims to determine the percentage of water absorbed by the sample immersed for 24 hours. 
Water absorption test was done to each dried sample in 24 hours immersion time at room temperature.

$$
\text { Water absorption }=\frac{m_{b}-m_{k}}{m_{k}} \times 100 \%
$$

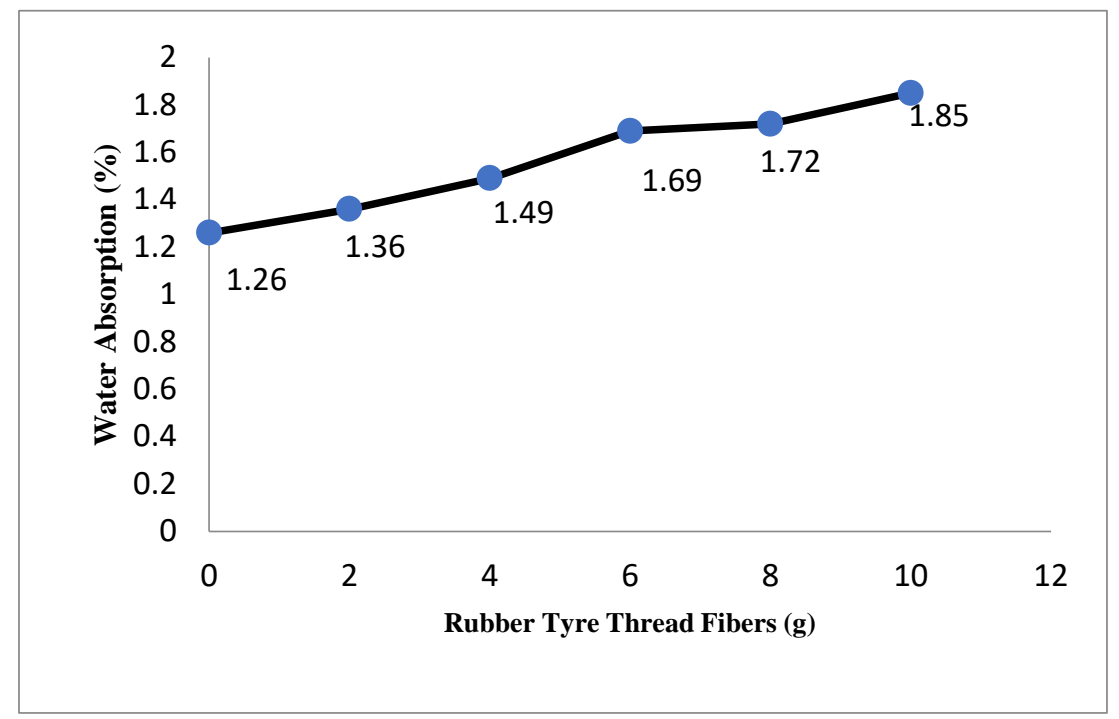

Figure 1. The Relationship between Water Absorption Rubber Thread Fibers Composition

Figure 1 shows that water absorption increases with the addition of thread fibers. The smallest water absorption is at $1.26 \%$ given by $(55: 20: 0: 10: 15) \%$ composition. From sample 1 , we can see that palm oil boiler ash can be used in tiles mixing as it has low water absorption. The biggest water absorption capacity was obtained at $(55: 10: 10: 10: 15) \%$ composition at $1.85 \%$ therefore the material was hydrophilic. This is caused by the void formed in the bonds between fibers and matrix. Consequently, pores occurred. Then, with the imperfect fibers' formation, the matrix was not able to fill the empty room in the sample. During the materials mixing, there were materials that were not entirely mixed well. However, water absorption obtain was still within the normal range. This was proven by the biggest water absorption value obtained was relatively smaller compared to Indonesian National Standard (SNI) 0096:2007 which is at $10 \%$.

Density is the comparison of a substance's mass with its volume. Density is a characteristic of every substance. Therefore, different materials have different density. It can be measured mathematically by:

$$
\rho=\frac{m}{V}
$$




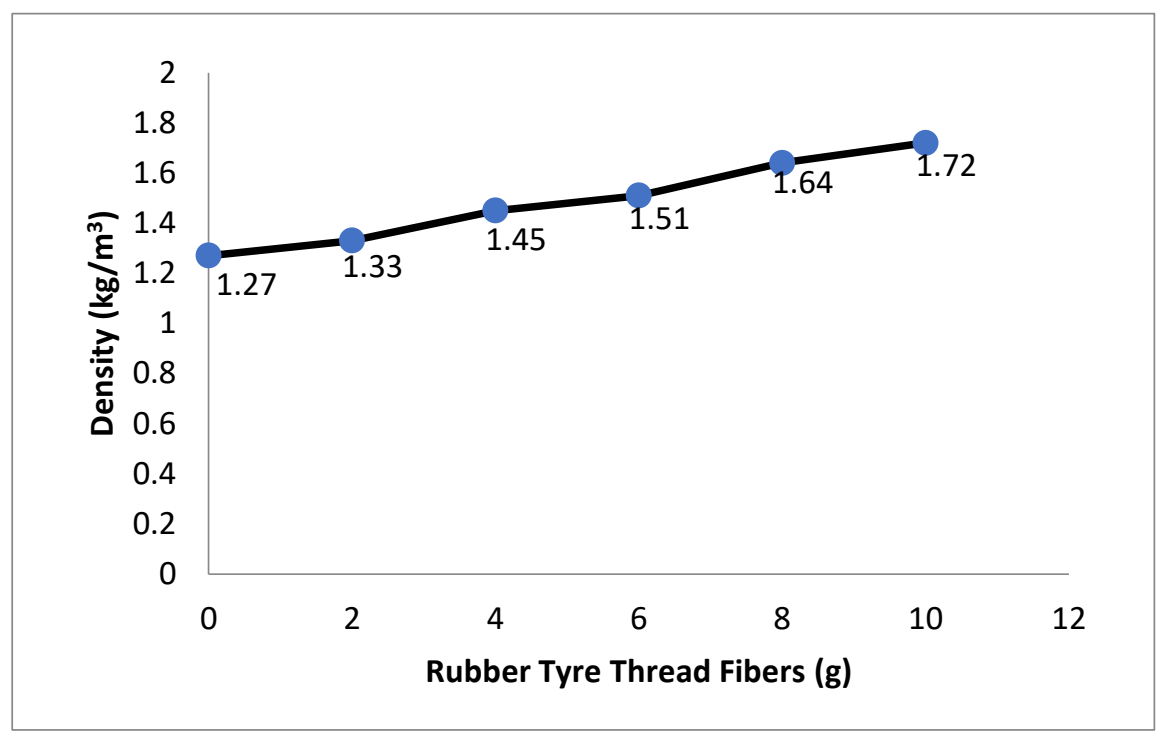

Figure 2. The Relationship between Density and Rubber Thread Fibers Composition

There is an upward trend relationship between density and the addition of rubber thread fibers composition shown in Figure 2. The more rubber thread fibers added the higher the density was. This is because the atoms that constructed the polymer composite tiles formed strong and solidified bonds when pressed at high temperature. Consequently, the volume increased for polymer composite tiles. The lowest density was $1.27 \mathrm{~g} / \mathrm{cm}^{3}$ while the highest was $1.72 \mathrm{~g} / \mathrm{cm}^{3}$ obtained from $(55: 20: 0: 10: 15) \%$ and $(55: 10: 10: 10: 15) \%$ compositions respectively.

\subsection{Mechanical Properties Analysis}

Impact test aims to determine sample strength against dynamic loading. The method used in this study for impact test was Charpy model where the sample of a pre-determined size was placed horizontally with both ends of samples were placed at the supports. Then the dynamic load was suddenly released towards sample with a $160^{\circ}$ of initial load vertical angle. The impact strength (Is) produced is the ratio between energy absorbed (Es) and cross-section area (A).

$$
I_{S}=\frac{E_{S}}{A}
$$

Figure 3 shows sample 1 with $(55: 20: 0: 10: 15) \%$ composition has the smallest impact strength of $24.63 \mathrm{~kJ} / \mathrm{m}^{2}$. This composition only consisted of matrix as the binder, sand as coarse aggregates and boiler ash as fine aggreagtes but without fibers as an effective inertia force. The highest impact strength was obtained at $77.68 \mathrm{~kJ} / \mathrm{m}^{2}$ from sample 5 with $(55: 12: 8: 10: 15) \%$ composition. The composition of matrix was constant therefore the particles between aggregates and fillers is bonded well with each other by asphalt and epoxy resin whose functions are as binders to form strong bonds between asphalt, epoxy resin, coarse aggresgate sand and fines aggregates boiler ash as fillers in the hollow space between aggregate granules and the pores in it. Therefore, there was bonds strengthen between the matrix and filler. However in sample 6, 
there was a redction in the impact strength. This was caused by the excess additions of fibers which led to the saturation in samples therefore asphalt and resin as the binders were unable to bond the entire sample.

Flexural strength test was intended to observe polymer's endurance towards the load given. The method used was three-point flexural test. The testing was also meant to observe the elasticity of a material. The weight was hung at the load and the span support was placed on an iron disk. Span was arranged to be at $80 \mathrm{~mm}$ away from each other and the sample was placed in the middle of span. The maximum load scale was set at $100 \mathrm{kgf}$ and speed of $20 \mathrm{~mm} /$ minute. The load display and strain were exactly at zero scale.

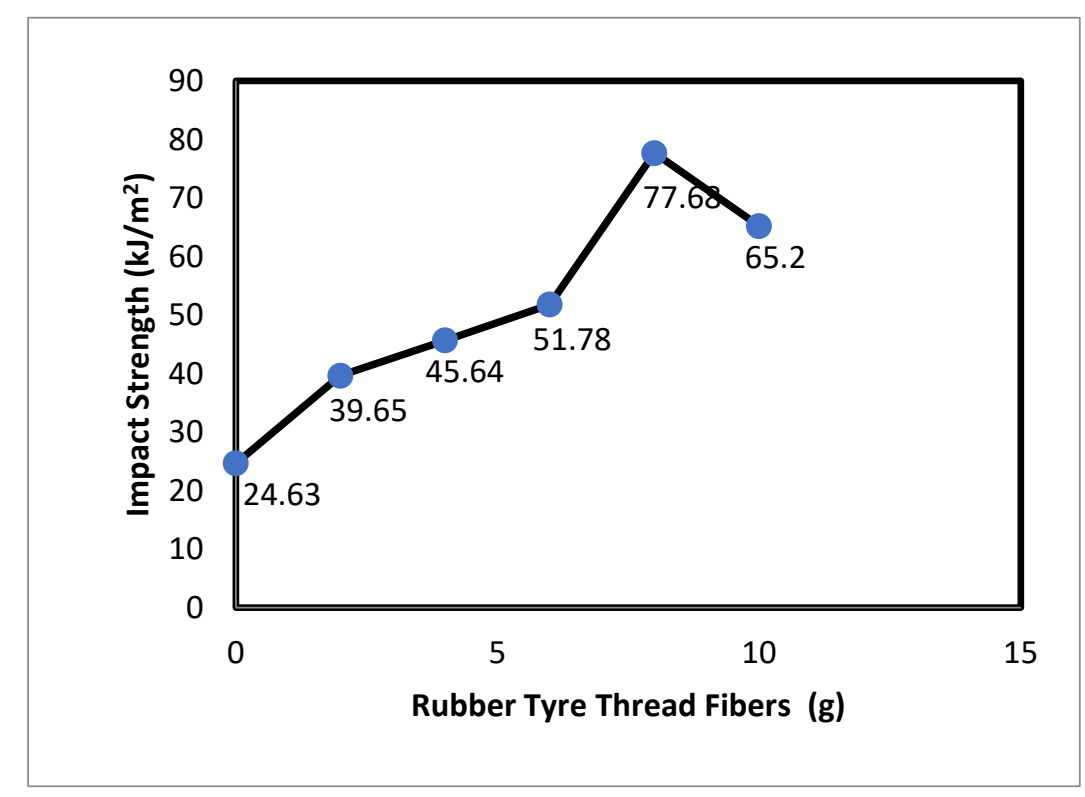

Figure 3. The Relationship between Impact Strength and Rubber Thread Fibers Composition

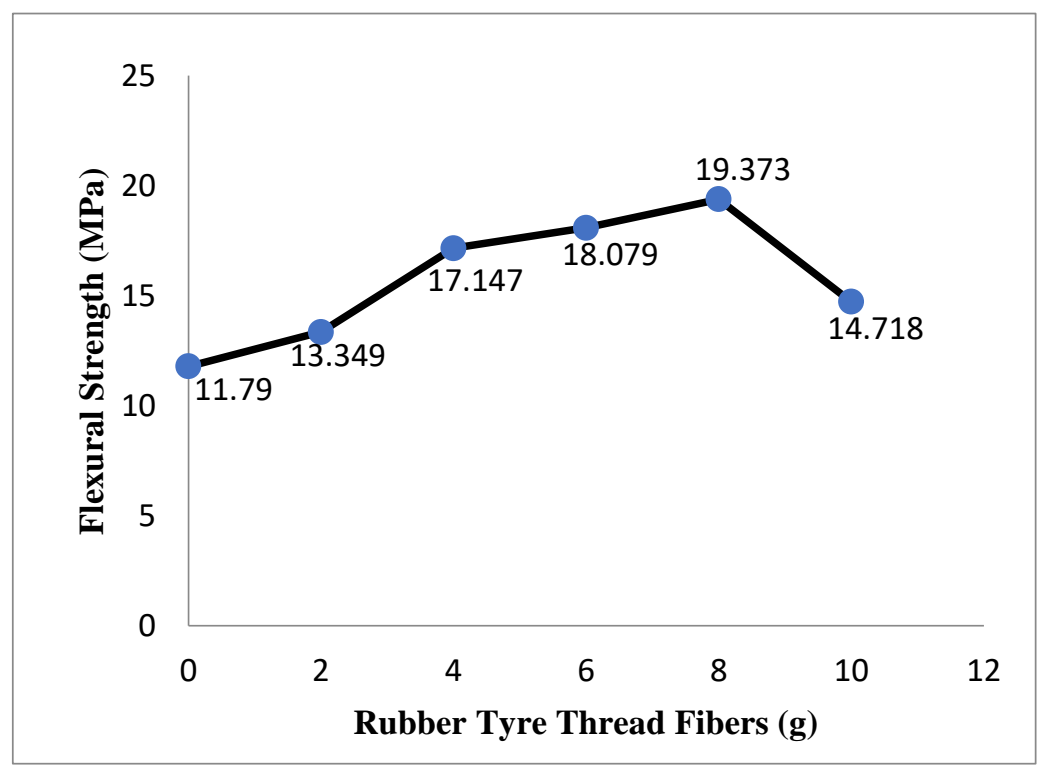

Figure 4. The Relationship between Flexural Strength and Rubber Thread Fibers Composition 
Figure 4 above shows that the specimen's flexural strength is influenced by the composition of the constituents material. Sample 1 was not strengthen by the fibres and had 11.79 Mpa flexural strength. The best result was obtained with the addition of fibres, given by sample 5 with 19.373 Mpa strength. The addition of fibers increases flexural strength. This means that the continuous placement of thread fibres from rubber tyre is able to add the flexural strength of polymer composite roof tiles. However on sample 6, there was a decrease on the strength which might be caused by the uneven distribution of fibers in the tested sample.

\subsection{Thermal Properties Analysis}

One characteristic of polymer material is its susceptibility to temperature changes as molecules movement due to thermal will alter the structures or group of molecules (especial to big dimension structures). Such condition affects mechanical properties. In order to observe thermal properties, thermal analysis like DTA can be used.

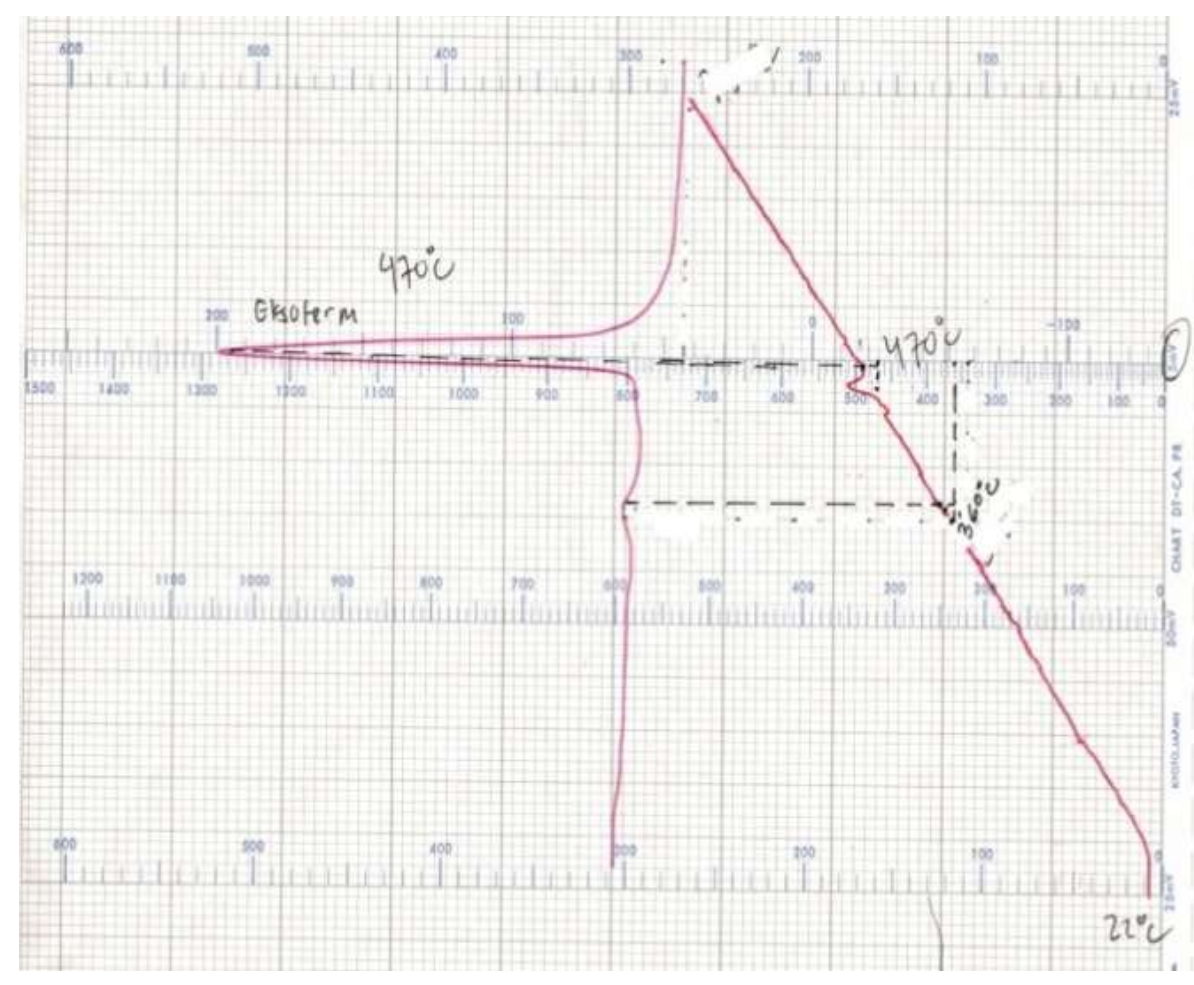

Figure 5. DTA Test on Polymer Roof Tiles Sample with 10\% Addition of Rubber Tire Thread Fibers

Figure 5 is a sample with $(55: 10: 10: 10: 15) \%$ composition which obtained the best thermal analysis of $360^{\circ} \mathrm{C}$ temperature from Differential Thermal Analysis (DTA) test. The addition of rubber thread fibers leads to better thermal value where the heat absorbed breaks the molecule chains and the presence of air causes oxidation process in the roof tiles. There is a change of form during combustion. 


\section{Conclusion}

1. The best composition of sand, oil palm boiler ash, thread fibers of used rubber tire, asphalt and epoxy resin for physical, mechanical and thermal properties is $(55: 12: 8: 10: 15) \%$. The water absorption is $1.72 \%, 1.64 \mathrm{~g} / \mathrm{cm}^{3}$ density, impact strength of $77.68 \mathrm{~kJ} / \mathrm{m}^{2}$ and 19.37 Mpa flexural strength which can give good density, strength and flexibility. The result of this study meets the standard from SNI 0096:2007 in which the maximum water content is $10 \%$.

2. Physical strength from polymer roof tiles is influenced by the addition of rubber tire thread fibers used. The absorption water value and density increase with the increase of thread fibers added. This affects the impact and flexural strengths where the values increase with the addition of rubber thread fibers.

3. The result of polymer composite roof tiles study has successfully met Indonesian National Standard (SNI) for roof tiles with $1.72 \%$ water absorption in which the value is still below $10 \%$ of SNI standard. Moreover, the result shows good impact strength $77.68 \mathrm{~kJ} / \mathrm{m}^{2}$ and 19.373 Mpa flexural strength which are better than the previous studies of polymer roof tiles. Suryati (2012) made and characterized polymer composite roof tiles from a mixture of polyester, asphalt, used Styrofoam and long palm fibers. Maximum value was obtained at $(29: 5: 1: 61: 4) \%$ with $5.4 \%$ water absorption, $18 \mathrm{~kJ} / \mathrm{m}^{2}$ impact strength and $7.7 \mathrm{Mpa}$ flexural strength.

\section{REFERENCES}

[1] Adriana, Polimer Nanokomposit Berbasis Polistirena dan Nanokristal Selulosa Tandan Kosong Sawit Menggunakan Aditif Antistatik Gliserol Monostearat untuk Bahan Teknis, Medan: FMIPA Universitas Sumatera Utara, 2014.

[2] Y. Qin, Y. He, B. Wu, S. Ma and X. Zhang, "Regulating Top Albedo and Bottom Emissivity of Concrete Roof Tiles for Reducing Building Heat Gains," Energy and Buildings, vol. 156, pp. 218-224, 2017.

[3] M. Santamouris, "Cooling the Cities - A Review of Reflective and Green Roof Mitigation Technologies to Fight Heat Island and Improve Comfort in Urban Environments," Solar Energy, vol. 103, pp. 682-703, 2014.

[4] A. E. Pramono, Karakteristik Komposit Karbon-Karbon Berbasis Limbah Organik Hasil Proses Tekan Panas, Depok: Fakultas Teknik Universitas Indonesia, 2012.

[5] C. J. Molineux, C. H. Fentiman and A. C. Gange, "Characterising Alternative Recycled Waste Materials for Use as Green Roof Growing Media in the UK," Ecological Engineering, vol. 35, no. 10, pp. 1507-1513, 2009.

[6] A. E. Lavat, M. A. Trezza and M. Poggi, "Characterization of Ceramic Roof Tile Wastes as Pozzolanic Admixture," Waste Management, vol. 29, no. 5, pp. 1666-1674, 2009.

[7] F. Bisceglie, E. Gigante and M. Bergonzoni, "Utilization of Waste Autoclaved Aerated Concrete as Lighting Material in the Structure of A Green Roof," Construction and Building Materials, vol. 69, pp. 351-361, 2014.

[8] A. S. M. A. Awal and S. I. Abubakar, "Properties of Concrete Containing High Volume Palm Oil Fuel Ash: A Short-Term Investigation," Malaysian Journal of Civil Engineering, vol. 23, no. 2, pp. 54-66, 2011.

[9] A. A. Kadir, Nur A. M. Zahari and N. A. Mardi, "Utilization of Palm Oil Waste into Fired 
Clay Brick," Advances in Environmental Biology, vol. 7, no. 12, pp. 3826-3834, 2013.

[10] V. Sata, C. Jaturapitakkul and K. Kiattikomol, "Utilization of Palm Oil Fuel Ash in HighStrength Concrete," Journal of Materials in Civil Engineering, vol. 16, no. 6, pp. 623-628, 2004.

[11] K. A. Shahid, M. A. Sulaiman, N. Ghazali, W. A. Rahman and A. Zukri, "Palm Oil Clinker as Drainage Layer in Green Roof System Under Malaysia Climatic Conditions," Journal of Engineering and Technology (JET), vol. 5, no. 2, pp. 27-37, 2014.

[12] K. Sembiring, E. Marlianto, Thamrin and R. Sani, "The Use of Solid Waste in Rubber Gloves Industry and Natural Polyurethane in Making Sound Dumping Polymer's Roof," American Journal of Physical Chemistry, vol. 3, no. 2, pp. 15-18, 2014.

[13] S. Budidarsono, A. Susanti and A. Zoomers, "Oil Palm Plantations in Indonesia: the Implications for Migration, Settlement/Resettlement and Local Economic Development," Biofuels-Economy, Environment and Sustainability, Book Chapter Ed. Zhen Fang, IntechOpen, pp 173-193, 2013.

[14] E. Hambali and M. Rivai, "The Potential of Palm Oil Waste Biomass in Indonesia in 2020 And 2030," In 2017 International Conference on Biomass: Technology, Application, and Sustainable Development IOP Conference Series: Earth and Environmental Science, vol. 65, no. 1, IOP Publishing, 2017.

[15] O. Pye, "A Plantation Precariat: Fragmentation and Organizing Potential in the Palm Oil Global Production Network," Development and Change, vol. 48, no. 5, pp. 942-964, 2017.

[16] Ermiyati, "Abu Kelapa Sawit sebagai Pengganti Sebagian Semen Terhadap Kuat Tekan dan Resapan Air pada Mortar," Jurnal Sains dan Teknologi , vol. 6, no. 2, pp. 31-34, 2007.

[17] O. Obire and R. Putheti, "The Oil Palm Tree: A Renewable Energy in Poverty Eradication in Developing Countries," Drug Invention Today, vol. 2, no. 1, pp. 34-41, 2010.

[18] S. Prasertsan and P. Prasertsan, "Biomass Residues from Palm Oil Mills in Thailand: An Overview on Quantity and Potential Usage," Biomass and Bioenergy, vol. 11, no. 5, pp 387-395, 1996.

[19] E. M. Ginting, Pengolahan dan Karakterisasi Abu Boiler Kelapa Sawit dan Abu Sekam Padi Menjadi Nanopartikel sebagai Bahan Pengisi Termoplastik HDPE, Medan: FMIPA Universitas Sumatera Utara, 2014.

[20] H. Rezk, A. M. Nassef, A. Inayat, E. T. Sayed, M. Shahbaz and A. G. Olabi, "Improving the Environmental Impact of Palm Kernel Shell Through Maximizing Its Production of Hydrogen and Syngas Using Advanced Artificial Intelligence," Science of The Total Environment, vol. 658, pp. 1150-1160, 2019. 